\title{
水の管内流サブクール沸騰熱伝達*
}

\author{
加治 増 夫*1, 古川雅 裕*2 \\ 森幸 治*1，世古口言彦*1
}

\section{Subcooled Boiling Heat Transfer to Water Flowing in a Tube}

\author{
Masuo KAJI, Masahiro FURUKAWA, \\ Koji MORI and Kotohiko SEKOGUCHI
}

\begin{abstract}
An experimental study on the boiling heat transfer to water flowing in a tube at pressures of $0.3,0.5,1$ and $2 \mathrm{MPa}$ was conducted. Based on the data in the subcooled boiling region, a heat transfer model, in which the heat flux was postulated to consist of forced convection and nucleate boiling contributions, was developed. The forced convection heat flux was evaluated by the single-phase convective heat transfer correlation by taking into account the effect of increase in liquid velocity due to net vapor generation. The nucleate boiling heat flux is determined from an empirical correlation that takes into consideration promotive and suppressive effects on the incipience of boiling. The present model was compared with the experimental data and various known correlations and satisfactory results were obtained.
\end{abstract}

Key Words: Heat Transfer, Multiphase Flow, Boiling, Two-Phase Flow, Flow Boiling of Water, Subcooled Boiling Heat Transfer

\section{1 . 緒}

サブクール沸滕現象は, 液相から気相への変化,す なわち蒸発を伴う熱交換器内部ではしばしば見られる が, 気泡の成長と减退が微妙なバランスの下に生起す る現象であるため, 熱流動的観点からは十分な予測解 析法が確立されていない。

サブクール領域における強制対流沸滕伝熱モデルに 対して，從来の研究では二通りの考え方がある．第一 のモデルは，伝熱面での気泡生成による熱輸送が支配 的な伝熱機構であると考え，プール沸騰や飽和核沸腾 領域と同様に扱えるとしたものである．この方法では 熱力学的平衡クォリティ $x$ が 0 のときの伝熱面過熱度 $\Delta T_{\text {sat }}$ と熱流束 $q$ の関係がサブクール領域でも成立す るとして，これを実験的に定めている。水の沸騰流に 対して, Jens-Lottes ${ }^{(1)}$, Thom ら ${ }^{(2)}$ は $\Delta T_{\text {sat }}$ を $q$ と压力 $P$ との関係式で与えているが，これらの相関式ではクオ リティ及び流速の影響は考虑されていない。

これに対して，サブクール沸騰の熱流束が強制対流 成分と沸騰成分から成るとしたモデルが提案されてい

* 佰稿受付 1996 年 8 月 2011 .

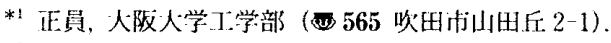

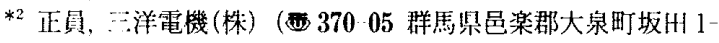
1 1)
る. Clark-Rohsenow ${ }^{(3)}$ は水の円管内流の実験值に対し て, 熱流束の各成分をそれぞれ単相流強制対流熱伝達 およびプール沸腾熱伝達の相関式で与えている。また， Bergles-Roshenow ${ }^{(4)}$ も同様な考え方で，単相流伝熱様式 からサブクール沸騰への移行を滑らかに接続する式を 提案している.しかしながら，これらの式ではいずれ も発達したサブクール核沸滕領域では流速の影響が考 慮されていない。，その後発表された，水以外の流体も 対象としたShah ${ }^{(5)}$, Liu-Winterton ${ }^{(6)}$, Kandlikar ${ }^{(7)} の$ 相関 式でもこのような計算法が踏襲されている。これらの 主な相関式は表 1 に示す通りである。

Sekoguchi ら(8) らは, 気泡生成に伴う液体の增速を考 虑して強制対流効果による熱流束成分を評価し, 実験 值と比較して定めた沸瘗成分との和で全熱流束を与え る方法を提案した。これを水の管内沸腾流の高熱流束 域の熱伝達係数の実験值と比較して，满足すべき結果 を得た。この方法では, 伀熱特性に及ほすクォリティと 流速の影響が考虑されることになる。

これらの予測法の妥当性は実験值との比較によって 検討されるが, 現在のところ基準とすべきデータは十 分であるとは言えない，本研究では，水を供試流体と して一連の条件で管内沸騰流の実験を行い, サプクー ルから，飽和核沸騰，強制对流蒸発の広笵囲にわたる 
Table 1 Correlations of subcooled boiling heat transfer

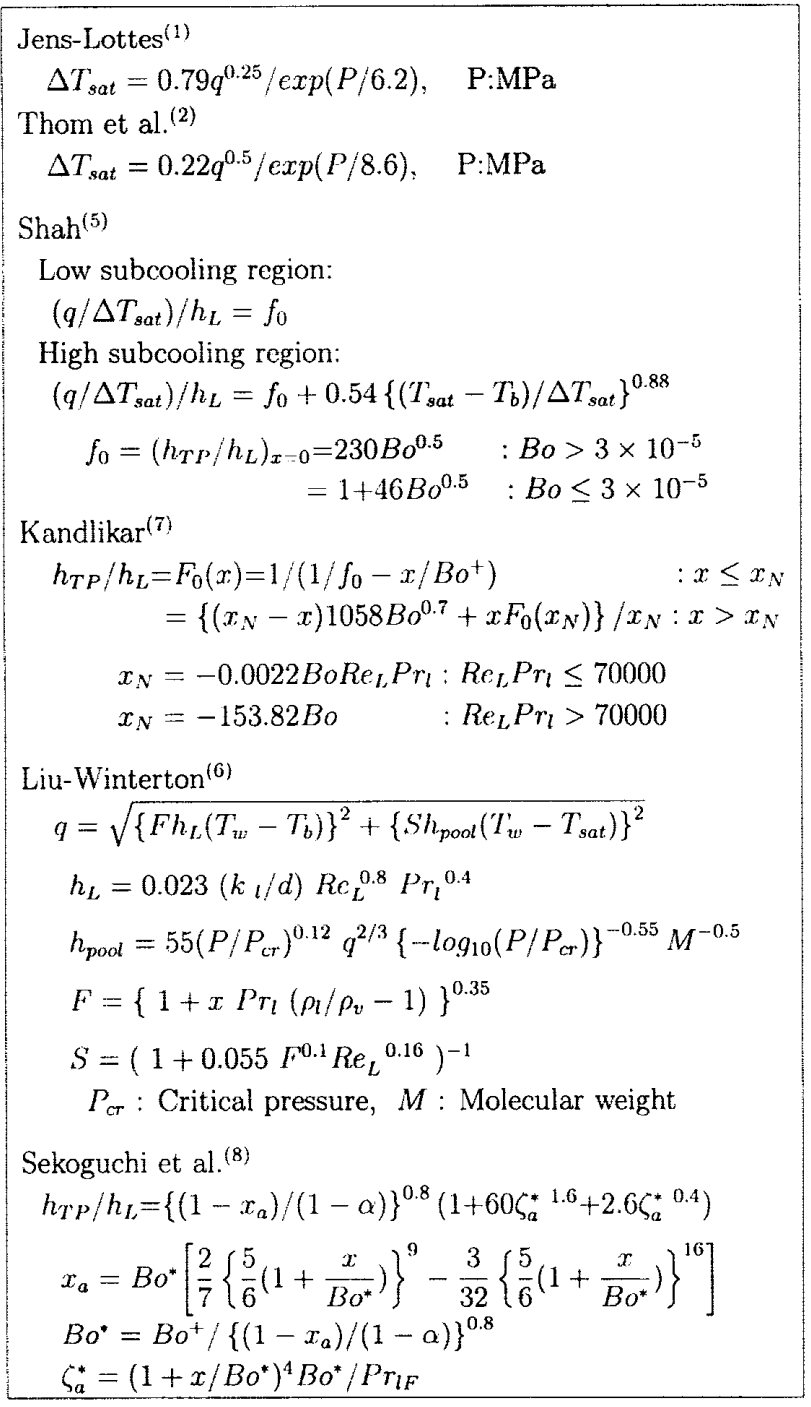

領域で実験データを収集し，比較・検討した。本報では サブクール領域についての結果と，新たに提案した熱 伝達係数の推算法について報告する。

\section{2、実赜装置および実験方法}

実験装置の概略を図 1 に示す、基本的には慨報(9) と问 様の強制循環ループで構成され，供試部は垂道上㧳流 である，循環にはダイヤフラムポンプを用い，加熱は 交流直接通電によった。加熱供試管は内径 $d=8.03 \mathrm{~mm}$, 外径 $9.99 \mathrm{~mm}$ のSUS304鋼管で作成し, 加熱長は $2 \mathrm{~m}$ と した，管壁温度は軸方向に $0.1 \mathrm{~m}$ のピッチで合計 19 箅所 の断面において，管軸に対して対称の位置に 2 対の外 径 $0.2 \mathrm{~mm} \mathrm{E}$ 型（CRC）熱電対を取付け測定した，加熱用 電極の位置には静玨孔を設け，差压の測定值から温度 湘定断面での局所の静圧を推定した。熱電対による温

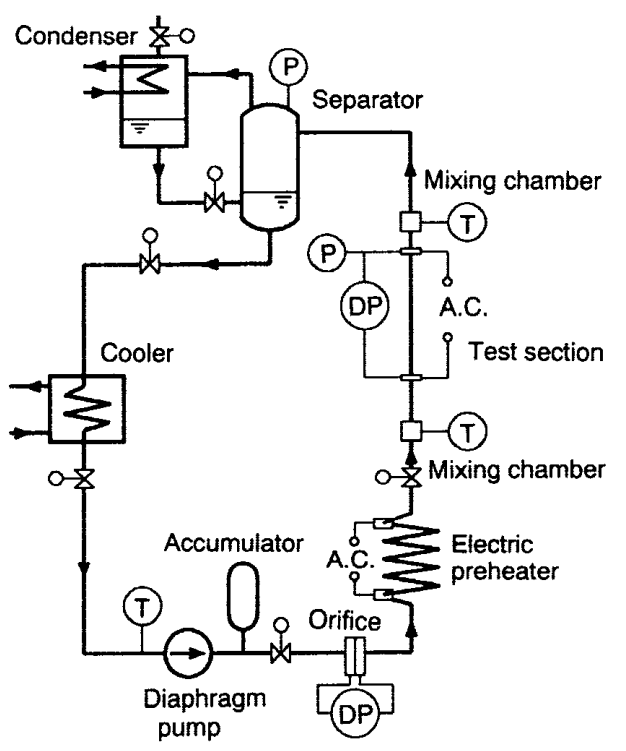

Fig. I Schematic diagram of experimental apparatus.

度測定精度は $\pm 0.15 \mathrm{~K}$ であり，管肉厚の測定誤差や放熱 の影響を考虑すると管内壁温度の推定值の誤差は約 \pm 0.2 Kと見積もられる。

実験は, 系玨力, 流量, 熱流束, 入日サブクールを種 々変えて行った。主な実験条件は次の通りである。

庄力 $P: 0.3,0.5,1.0,2.0 \mathrm{MPa}$

質量速度 $G: 500,750,1000 \mathrm{~kg} / \mathrm{m}^{2} \mathrm{~s}$

熱流束 $q: 3 \sim 50 \times \mathrm{W} / \mathrm{m}^{2}$

入口温度 $T_{\text {in }}: 85 \sim 245^{\circ} \mathrm{C}$

\section{3. 実 䟱 果}

図 2 は, 質量速度が一定で熱流束が異なる場合の, 熱 伝達係数 $h_{T P}$ と熱力学的平衡クォリティ $x$ の関係の例を 示す.一連の実験により, サブクールから飽和核沸騰, 強制対流蒸発に至る領域を包括したデータが得られた が，以下ではサブクール領域のみに限定して検討を進 める.なお, 著者らはほぼ同一内径の管を用いて淔 通電加熱方式による実験を行いそのデータを提示して いるが(9), 交流通電加熱方式による本実験結果ともよ く一致することが確認された。また, 図中の曲線は強 制対流蒸発域に対して得られた実験式である。

サブクールが十分大きい領域では，伝熱様式は液単 相の強制対流伝熱であるので, 熱伝達係数はほぼ一定 であるが,クオリティの増大と共に壁温が上昇し,やが て壁温が飽和温度をある程度上まわると沸滕が開始す る.したがって，沸睠開始点は熱流束に大きく传存し， 熱流束が大きいほど低いクオリティの領域から熱伝達係 数の増大が見られる。 
サブクール沸騰が生じ得るためには壁温 $T_{w}$ が飽和温 度 $T_{\text {sat }}$ 以上になる必要があるが, $T_{w}=T_{\text {sat }}$ となる点の クォリティを $-B o^{+}$とすると次式で表わされる.

$$
B o^{+}=\frac{c_{p}\left(T_{s a t}-T_{b}\right)}{h_{f g}}=\frac{q c_{p}}{h_{f g} h_{L}}
$$

ただし， $c_{p}$ は比熱， $T_{b}$ はバルク温度， $h_{f g}$ は蒸発潜熱で ある.また， $h_{L}$ は全流量が液単相で流れる場合の熱伝達 係数であり，本報では円管内乱流に対する Dittus-Boelter の式を用いて求めた.

$\mathrm{Bo}^{+}$の値は流量, 熱流束, 压力などによって異なる. 従って，クオリティを $x / B o^{+}$の形で表すことは, 壁温の 過熱度を考慮してサブクール度を表すことを意味し，物 性值，流量，熱流束が異なる条件に対しても同じ尺度 で比較することが可能になると考えられる。

図 3 は図 2 に示した実験值を，二相流と液単相流の 熱伝達係数の比 $h_{T P} / h_{L}$ と $x / B 0^{+}$の関係で示した結果で ある.沸騰の生じているのが明確な $q>10 \times 10^{4} \mathrm{~W} / \mathrm{m}^{2}$ の実験值を対象とした。図から, 熱流束が小さいほど 沸騰開始点が右に奇り, 壁温が飽和温度を越えてもす ぐには沸騰が生じないことが判る。また，同一の熱流 束では, 質量速度が大きいほど沸騰が生じにくくなって いる。

図には従来の相関式(1),(2),(8)による計算值を侀記した。 計算值の熱流束は実験值と対応しており, 熱流束が高い ほど熱伝達係数も高くなるような順に並んで表示され ている.Jens-Lottesの式(1)は実験值に比べてかなり低い 值をとる.Thomらの式(2)では沸滕開始点は明確に規定 されないが, 沸騰開始後の実験值とは比較的近い值と なっている。しかしながら，低熱流束の場合には満足す べき結果を示しておらず，前述のように質量速度の相 違による熱伀達係数の相違は予測できない，Sekoguchi ら (8)の計算值は高熱流束では実験值と比較的よく一致 しているが， $q / G$ が小い場合は流量の影響を過大評価 していくぶん低めの熱伝達係数を与える傾向がある。

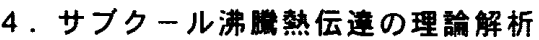

4. 1 熱伝䢖係数の定童本報で用いた解析方法は， Sekoguchiら (8)が既に報告した方法を基礎にして修正を 行ったものであるが，以下で简単に説明する。

サブクール領域における沸騰流の熱流束 $q$ が沸騰効 果成分 $q_{b}$ と強制対流効果成分 $q_{c}$ から成るとすると,

$$
q=q_{b}+q_{c}
$$

全熱流束に対する熱伝達係数を $h_{T P}$, 強制对流伝熱効果 による熱伝達係数を $h_{c}$ とすると, 次式で定義される。
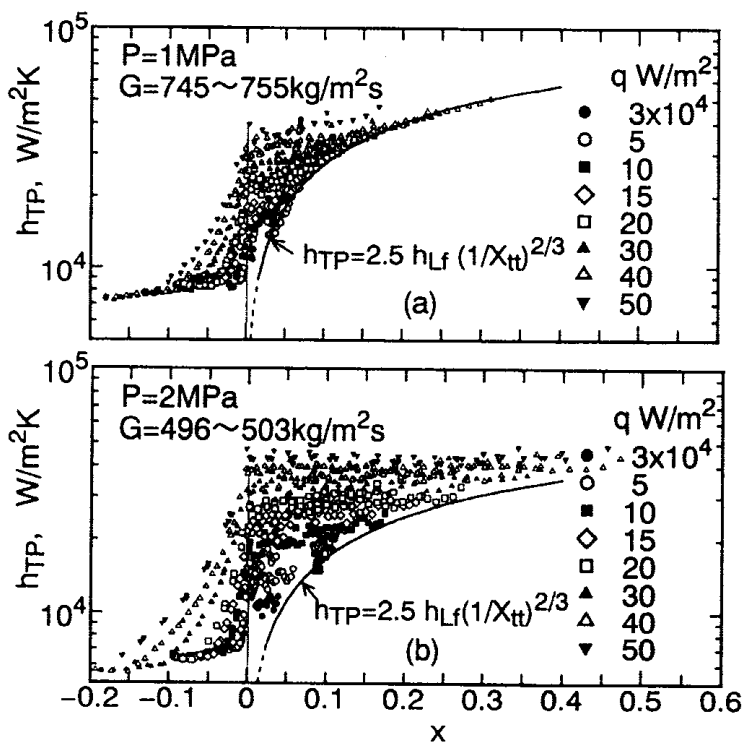

Fig. 2 Flow boiling heat transfer data $h_{T P}$ plotted aginst thermodynamic equilibrium quality $x$.

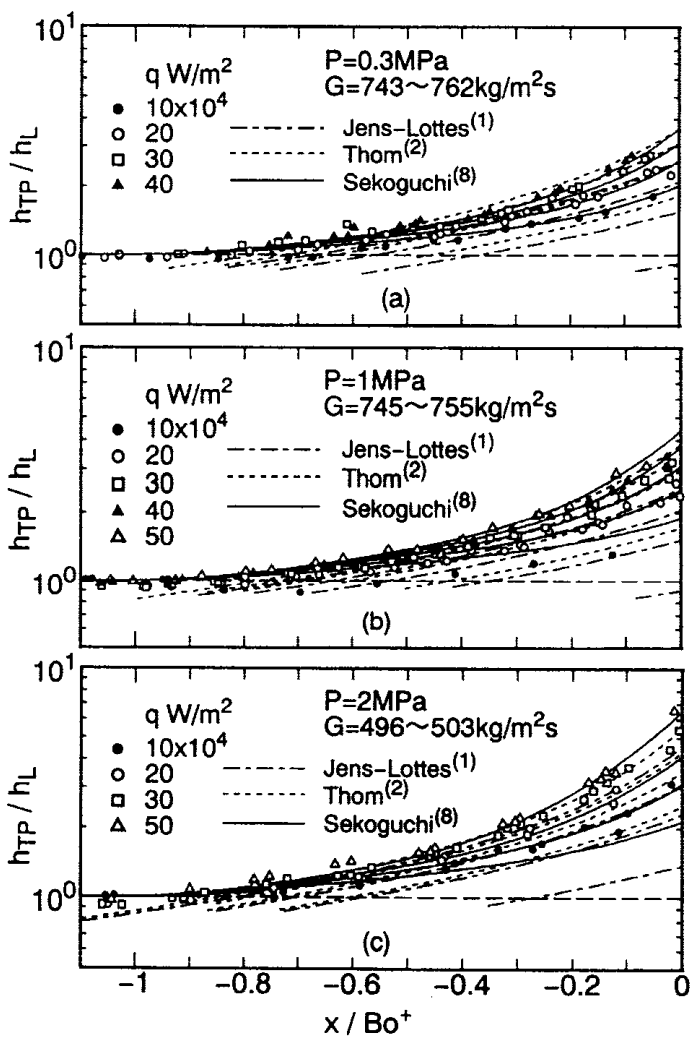

Fig. 3 Comparison of experimental data $h_{T P} / h_{L}$ with various correlations in the subcooled region.

$$
\begin{aligned}
& h_{T P}=q /\left(T_{w}-T_{b}\right) \\
& h_{c}=q_{c} /\left(T_{w}-T_{b}\right)
\end{aligned}
$$


式(2)〜(4)から次の関倸が得られる.

$$
\frac{h_{T P}}{h_{c}}=\frac{q}{q_{c}}=\frac{1}{1-q_{b} / q}
$$

強制対流による熱伝達係数 $h_{c}$ は, 単相流の熱伝達係 数 $h_{L}$ に对して, 気泡体䅡による速度の增大を考慮した 形で与えられる，すなわち，真のクオリティを $x_{a}$, ボイ ド率を $\alpha$ とすると, 沙体の質量流量は気体に变化した量 だけ减少するため $\left(1-x_{a}\right)$ 倍となるが, 流速は $1 /(1-\alpha)$ 倍に增加する． $h_{L}$ は予備実験での単相流の測定值から Dittuds-Boelterの式とよく一致することが確認された. したがって，熱伝達係数は平均流速の 0.8 乘に比例する ことから， $h_{c}$ は次式で表される。

$$
h_{c} / h_{L}=\left\{\left(1-x_{a}\right) /(1-\alpha)\right\}^{0.8}
$$

式(5)，(6)から次の関係を得る.

$$
\frac{h_{T P}}{h_{L}}=\left(\frac{1-x_{a}}{1-\alpha}\right)^{0.8} \frac{1}{1-q_{b} / q}
$$

4. 2 真のクォリティとボイド率の推算方法サブク一 ル領域に掠ける真のクオリティ及びボイド率の推定法は 種々提案されている. Sekoguchiら(10) は，サブクール領 域における液体の洫度分布は, 沸滕のある場命でも伝 熱面近傍の気泡屏を除けば, 液単相の強制対流伀熱に よる温度場と一致すること、また，このときの過熱波 首はきわめて薄いことを見出した，この事军に基づき， 速度及び温度分有が坚相流之同様 $1 / 7$ 乗則分有に従い, 壁面近傍の過熱液層に相当する液体が気体に变換され るものとして，真のクォリティ $x_{a}$ 及びボイド率 $\alpha$ を推定 する力法(11)を提案している，以下でもこれとほぼ同様 にして真のクォリティ $x_{a}$ とボイド率 $\alpha$ を求めた.

サブクール領域における流体の速度，温度分布は単 相流のそれと相似であるとして $1 / 7$ 乘則に従うと仮定す る。ただし，沸騰に伴う気泡生成のため，前述のように 液体の速度が增加するものと考えると, 熱伝達係数は 式(7)で与えられる。この熱伝達係数によって壁面から の熱流束が流休に伝えられることから，仮想的な流れ の管断面内の温度分们が決定される。

サブクール沸騰が生ずる条件では壁面付近で液体は 過熱犾態となっているが, 壁面から離脱した気泡が液 体中に平衡を保って存在するためには，ある大きさの 過熱度 $\Delta T_{s}$ が必要である、 $\Delta T_{s}$ は, 気泡形状を直径 $d_{b}$ の球とすると近似的に次式で表される。

$$
\Delta T_{s}=\frac{4 T_{s a t} v_{g} \sigma}{h_{f g} d_{b}}
$$

ただし， $v_{g}$ は蒸気の比容積， $\sigma$ は表面張力である $d_{b}$ に ついての詳細は不明である，壁面のキャビティとなり得 る最大粗さに対応して $d_{b}=5 \mu m$ とすると, 压力 $0.3,0.5$, 1. $2 \mathrm{MPa}$ に対してそれぞれ $\Delta T_{s}=4.76,2.92,1.47,0.71 \mathrm{~K}$ となる、サブクール液中で消滅する気泡の最小径につ いての情報はないが，ここでは $d_{b}=5 \mu m$ を用いた。

以上の考えに基づき，壁面近くの液体のうち $\left(T_{s a t}+\Delta T_{s}\right)$ より高い温度に相当する熱量が蒸発に費やされるもの として, 蒸発量から次式により真の乾き度 $x_{a}$ を推定 した.

$$
x_{a}=\frac{2 \int_{r^{*}}^{r_{i}} c_{p}\left(T-T_{s a t}-\Delta T_{s}\right) \rho_{l} u r d r}{r_{i}^{2} G h_{f g}}
$$

ただし， $\rho_{l}$ は波体密度， $u$ は速度、rは半径座標であり， $r_{i}, r^{*}$ はそれぞれ管内半径, 及び $T=T_{s a t}+\Delta T_{s}$ となる 位睨の半径座摽である。

以上のように推定した $x_{a}$ から, Zuber-Findlay ${ }^{(12)}$ のド リフトフラックスモデルによりボイド率 $\alpha$ を求めた. 父泡流：

$$
\alpha=\frac{j_{g} /\left(j_{g}+j_{l}\right)}{1-0.2 \sqrt{\frac{\rho_{g}}{\rho_{l}}}+\sqrt{2} \frac{\left\{\sigma g\left(\rho_{l}-\rho_{g}\right) / \rho_{l}{ }^{2}\right\}^{1 / 4}}{j_{g}+j_{l}}}
$$

スラグ流 :

$$
\alpha=\frac{j_{g}}{1.2\left(j_{g}+j_{l}\right)+0.35 \sqrt{g d\left(1-\rho_{g} / \rho_{l}\right)}}
$$

ここで, $g$ は重力加速度, $j_{g}, j_{l}$ は気体及び液体のみか け速度であり, 次式で表される。

$$
j_{g}=G x_{a} / \rho_{g}, \quad j_{l}=G\left(1-x_{a}\right) / \rho_{l}
$$

ただし，気泡流とスラグ流の選移境界は雨式の交点か ら定まるが， $\alpha \cong 0.4$ であった， $x_{a}$ の值は以上の関係式 を用い，逐次繰り返し数值計算によって求めた。なお， $\alpha$ Smith ${ }^{(13)}$ の式で計算した場合も，本研究の対象籁囲 では最終の計算結果にほとんど差がなかった。

4.3 熱流束の沸腆効果成分 $q_{b}$ の相阅式図 4 は熱 伀達係数 $h_{T P}$ の実験值と, 上述の方法で推定した強制 対流成分 $h_{c}$ を比較した例である. 図には既報(9)の実験 值も併記している，xが小さい領域では沸腾が生じない ため気泡生成はなく, 従って, 単相流であるため $h_{T P}$ と $h_{c}$ はほぼ一致している， $x$ の増大とともに沸騰効果に より $h_{T P}$ は急激に大きくなり， $h_{c}$ との差も次第に增して いる．図に示すように熱流束が一定の場合, 質量速度が 小さいほど $h_{T P}$ が $h_{c}$ から離れていく $x$ は小さくなる.

さて， $h_{c}$ の推算值が得られると, 式(4)によって沸滕 效果による熱流束成分 $q_{b}$ を求めることができる。すな 


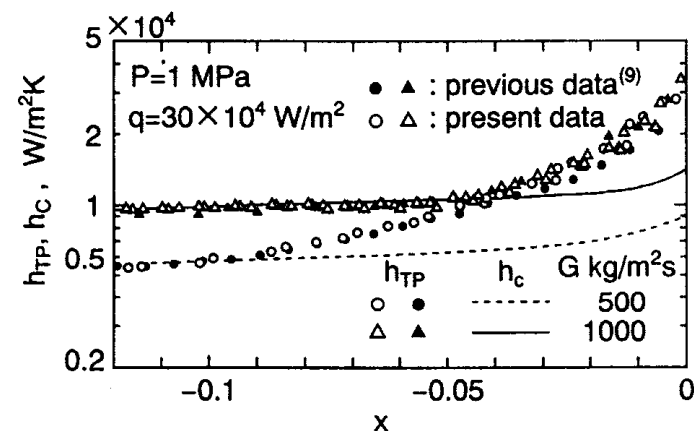

Fig. 4 Comparison of heat transfer coefficient data $h_{T P}$ with calculated forced convection contribution $h_{c}$

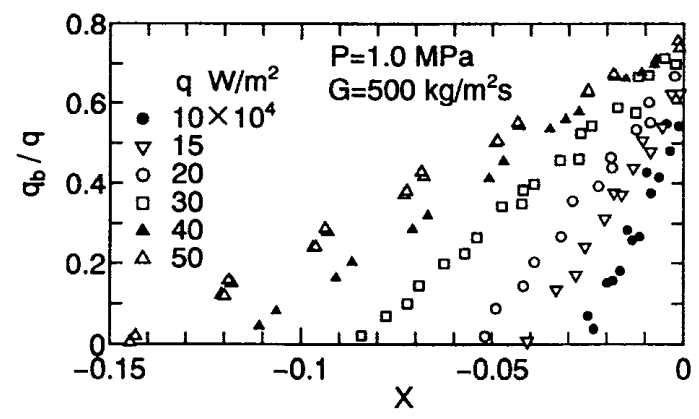

Fig. 5 Relation between necleate boiling heat flux component $q_{b} / q$ and quality $x$.

わち,

$$
q_{b} / q=1-q_{c} / q=1-h_{c} / h_{T P}
$$

図 5 は以上の計算によって求めた $q_{b} / q$ と $x$ の関係を示 す. 熱流束が大きくなるほど $q_{b} / q$ は大きく，より低いク オリティから沸騰効果が大きくなっていることが判る.

図 6 はクォリティを相対的に表した $\left(1+x / B 0^{+}\right)$と $q_{b} / q$ の関係を示す．横軸の 0 は $x=-B o^{+}, 1$ は $x=0$ の点 に対応し， $x=-B 0^{+}$の点では沸腾は生じていない．同 一熱流束の実験值はほほ一直線上にあり，それらを横 軸に平行移動すれば実線で示す一つの直線関係で表さ れるものと推察される。その移動距離は $q_{b} / q$ が0とな る点, すなわち沸腾開始点の $\left(1+x / B o^{+}\right)$の值に対応す ることになり，沸滕關始の遅延効果を表す。この值は熱 流束が大きいほど小さいことから，気泡生成の助成因 子として熱流束 $q$ を含む無次元量 $B o$ を考虑し，Bo が最適であるとの結論を得た．

図 7 はその整理結果を示す，同一の圧力，質量速度 の実験值がほほ一つの直線でまとめられることが判る. ただし，沸滕開始の遅延効果，すなわち $B 0^{-0.54}$ に掛かる 係数は高量速度ほど大きくなっている，気泡生成の

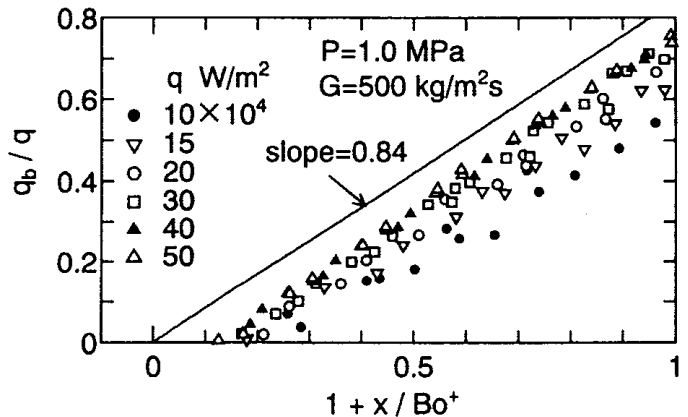

Fig. 6 Relation between $q_{b} / q$ and $1+x / B o^{+}$.
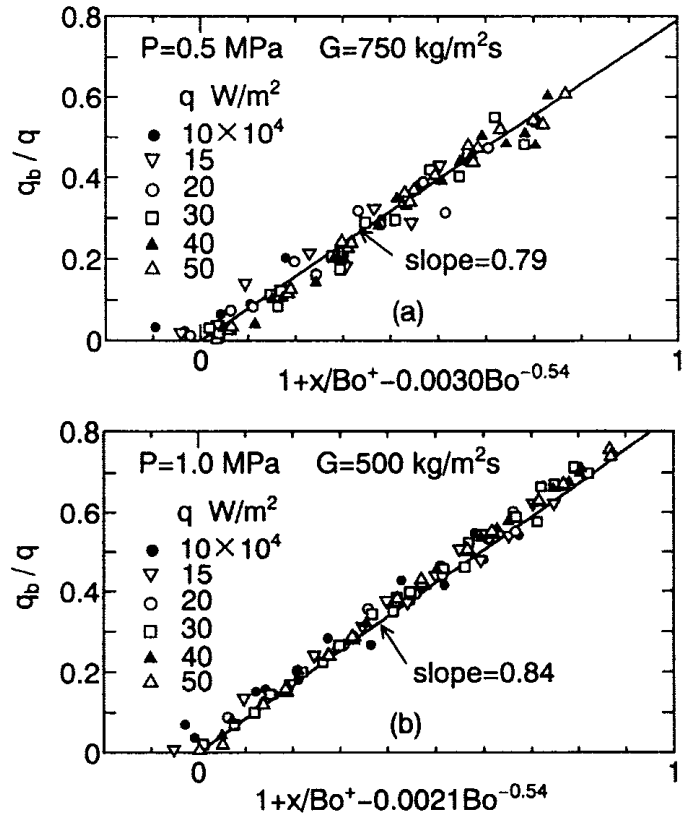

Fig. 7 Arrangement of $q_{b} / q$ data by considering the effect of boiling number Bo on ONB.

抑制因子として $G$ を含む無次元量 $R e$ の 0.38 乗を，また， 圧力などの物性值の影響を気液密度比 $\left(\rho_{l} / \rho_{g}\right)$ の 0.2 乗を 導入して実験值を再整理した結果を図 8 に示す. 図か ら判るように，異なった質量速度に対してもほぼ一つ の直線でまとめられる，ただし，圧力によって直線の傾 きが異なっている，核沸腾熱伝達に及ぼす圧力の影響 は従来の研究で詳細に調べられているが，それを表示 するパラメータとして決定的なものは得られていない. ここでは物性俌を代表するものとして，気液の密度を 考虑し $\rho_{g} / \rho_{l}$ を採用した。このようにして実験值を整理 し, 最終的に $q_{b} / q$ の相関式として次式を得た.

$$
\begin{aligned}
q_{b} / q=1.4\left(\rho_{g} / \rho_{l}\right)^{0.1} & \left\{1+x / B o^{+}\right. \\
- & \left.1.8 \times 10^{-5} R e^{0.38}\left(\rho_{l} / \rho_{g}\right)^{0.2} B o^{-0.54}\right\}
\end{aligned}
$$



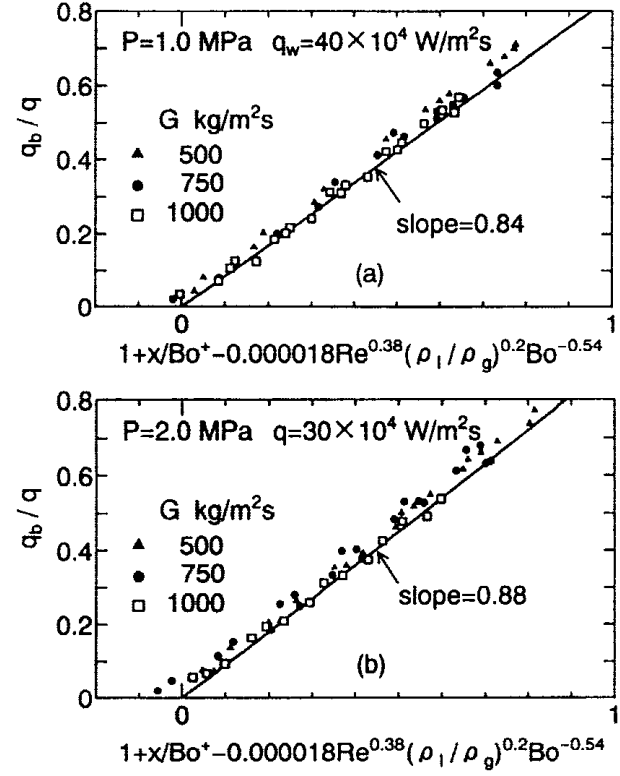

Fig. 8 Arrangement of $q_{b} / q$ by considering the effects of $R e$ and $\rho_{l} / \rho_{g}$ on ONB.
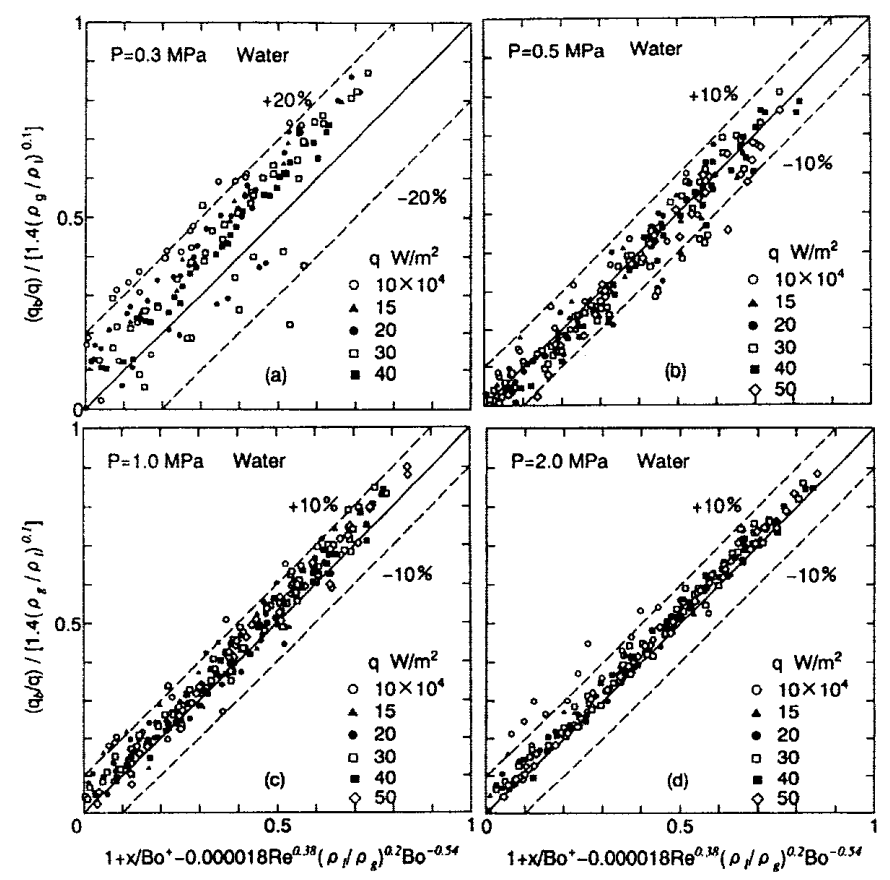

Fig. 9 Comparisons of experimental data with Eq.(14).

Table 2 Number of data and standard deviation in Fig.9

\begin{tabular}{|c|c|cc|}
\hline P(MPa) & Number of data & \multicolumn{2}{|c|}{ Standard deviation } \\
\hline 0.3 & 236 & $6.51 \%$ & $(1.92 \%)$ \\
\hline 0.5 & 282 & $5.96 \%$ & $(1.67 \%)$ \\
\hline 1.0 & 333 & $5.48 \%$ & $(1.86 \%)$ \\
\hline 2.0 & 307 & $5.71 \%$ & $(2.16 \%)$ \\
\hline
\end{tabular}

式を推奖し， $x_{N}<x<0$ ではこれに修正を加えた式を 提案している. 実験值と比較すると, 高熱流束の条件 ではよく一致しているが，低熱流束では修正式による 計算值はかなり低い值となっている。

本計算法による值は全般的に実験值と良好な一致を 示しており，既報のSekoguchi ら ${ }^{(8)}$ の計算值に比べて，低 熱流束でも比較的よく一致している.また, 式(14)の関 係で明瞭にされた沸睠開始点についても，実験值と比 較的よく対応していることが判る。

$P=0.5 \mathrm{MPa}$ の場合に, 本計算值のみならず他の相 関式でも実験值より高い熱伝達係数を与える傾向があ る. Cooper ${ }^{(14)}$ は沸腾流の飽和領域における熱伝達に対 する压力の影響を調べ, 約 $0.5 \mathrm{MPa}$ より低圧の領域と 高圧の領域で不連続な傾向のあることを見出している が, 本実験結果でも同様な傾向が表れている. 現在のと ころ, 沸滕熱伝達に対する圧力の影響を表すパラメー 夕として一般的なものは得られていない，本研究では 


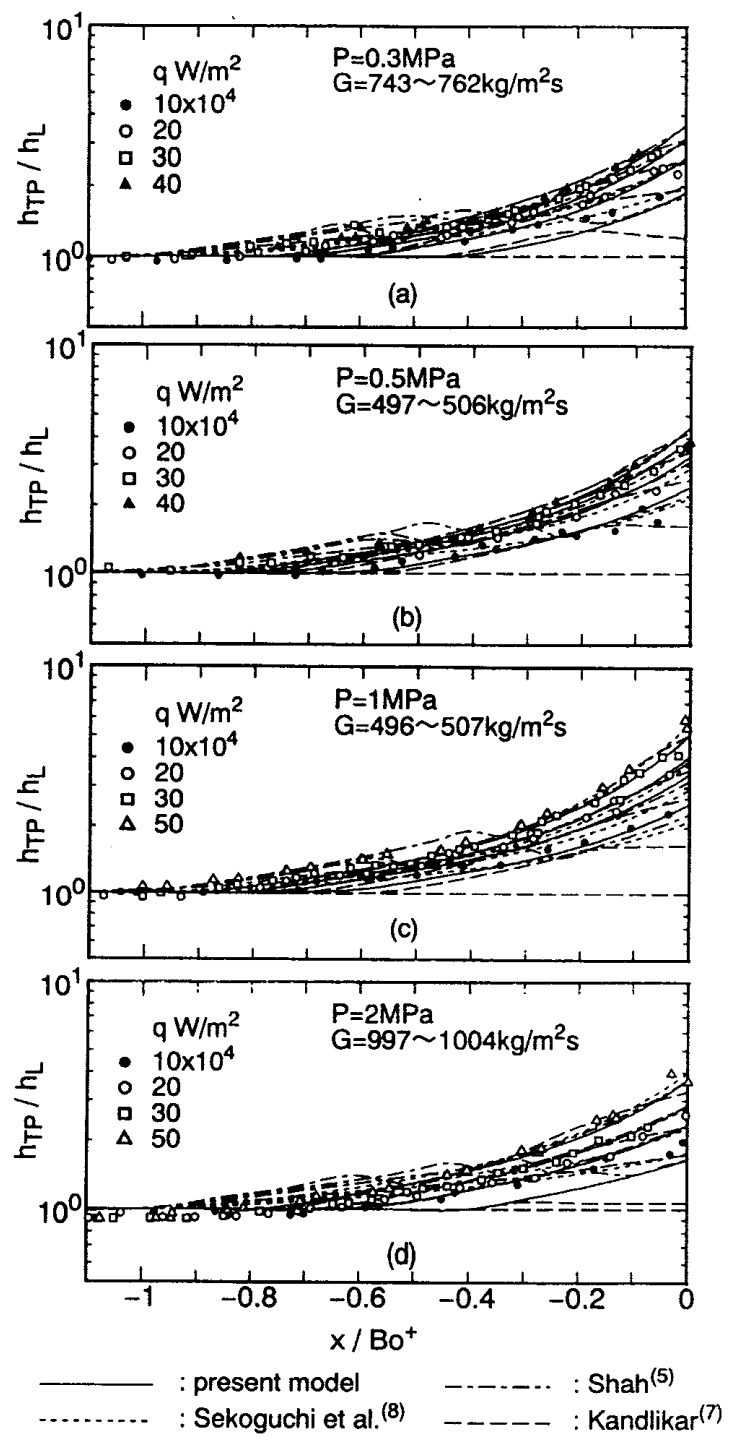

Fig. 10 Comparisons of experimental data of $h_{T P} / h_{L}$ with calculated values by the present model and other correlations.

式(14)のように $1.4\left(\rho_{g} / \rho_{l}\right)^{0.1}$ を用いたが, どのようなパ ラメータで表わすのが適当かは今後の課題である.

\section{4. 結言}

水を供試流体として管内垂直上昇流の沸騰伝熱実跧 を行い，サブクールから飽和核沸騰，強制対流蒸発に 至る広籁囲の領域で熱伝達係数を測定した。本報告で はサブクール領域の実験值について検討し, その伝熱 モデルを構築した。主な結果は以下の通りである。
（1）熱伝達係数の実験值を従来の各種相関式と比 較したところ，公籁囲の条件に対して適用性のあるも のは認められなかった。とくに，流竸の影響を考虑する 必要のあることが明らかとなった。

（2）物性值，流量，熱流束が異なる条件でのサブ クール沸腾熱伝達係数を比較するにあたって，クォリ ティ $x$ より壁温の過熱度を表す $x / B o^{+}$が有用であること を示した。

（3）サブクール領域における沸騰流の伝熱量が，強 制対流効果と沸騰効果の両成分から成るとする伀熱モ デルに基づき，熱伝達係数の推算法を提案した。この 方法は，世占口らによるポイド率の推算法(11)を基礎と しているが, 強制対流成分については液体の過熱を考 慮した式(8)による修正を加えて評価し，沸睠効果につ いては沸滕開始点を表す項を含む式(14)で与えている. 本推算法による計算值は, 全般的に実験值とよく一致 することを示した．

最後に本研究に協力された浜田幸一（住友金属工業）， 西住健治（関西電力）の両君に感謝の意を表します。

\section{文献}

(1) Jens, W.H. and Lottes, P.A., U.S. AEC Rep. ANL-4627, 1951.

(2) Thom, J.R.S. ほか 3 名, Proc. Instn. Mech. Engrs., 180, Pt 3C, (1965-1966), 226.

(3) Clark, J.A. and Rohsenow, W.M., Trans ASME, 76, (1954), 553.

(4) Bergles, A.E. and Rohsenow, W.M., Trans. ASME, Ser.C, 86, (1964), 365.

(5) Shah, M.M., ASHARE Trans., 83-1, (1977), 202.

(6) Liu, Z. and Winterton, R.H.S., Int. J. Heat Mass Transfer, 34-11, (1991), 2759.

(7) Kandlikar, S.G., Trans. ASME, Ser.C, 113-1, (1991), 190.

(8) Sekoguchi, K. ほか 4 名, Proc. 7th Int. Heat Transfer Conf., 4, (1982), 243.

(9) Sekoguchi., K. ほ 4 名 Dynamic of Two-Phase Flows, CRC Press, (1992), 669.

(10) Sekoguchi, K. ほか 4 名, Proc. 5th Int. Heat Transfer Conf., 4, (1974), 180.

(11) 世古口・ほか 3 名, 機論, 46-401, (1980), 111.

(12) Zuber, N. and Findlay, J.A., Trans ASME, Ser.C, 87-4, (1965), 453.

(13) Smith, S.L., Proc. Instn. Mech. Engrs., 184-1, No.36, (1969-1970), 647.

(14) Cooper, M.G., Int. J. Heat Mass Transfer, 32-3, (1989), 459. 